\title{
D. M.
}

\section{Peter Blaho}

Vzpomínat na toho, kdo odešel je vždy těžké, o to obtížnější to je, když se jedná o někoho, jehož jsme znali velmi dlouho a s nímž nás pojily dlouholeté pracovní vztahy i přátelství. Hodnocení osobnosti profesora Blaha z vědecké a pedagogické stránky i shrnutí jeho životních osudů ponechám jeho kolegovi z trnavské univerzity, který je k tomu nepochybně povolanější. Dovolím se zaměřit na jeden z aspektů jeho působení, pro nezasvěceného možná nečekaný, ale pro vykreslení osobnosti Petera Blaha o to důležitější.

Jedná se o jeho úzký vztah k Čechám, češtině a stejně tak, říci především by jistě nebylo správné, k české právní romanistice a jeho spolupráci s jejími představiteli. Jistě to nebylo dáno tím, že jeho manželka pochází ze západní části našeho bývalého společného státu. I to ale přispělo k tomu, že se v jeho knihovně nacházelo tolik knih krásné literatury v češtině.

Věnujme se ale jeho úzkým vztahů k Česku po odborné stránce. Nedokládají to ani tak jeho odborné studie publikované v českých odborných časopisech. Jednalo se o záležitost vždy zcela běžnou. Za pozoruhodné však již lze mít, že v Právněhistorických studiích pražské právnické fakulty publikoval svou bibliografii „Štát a právo antického Ríma. Bibliografia československých štúdií za roky 1945-1975“, ${ }^{1}$ kterou postupně doplňoval. ${ }^{2}$ V roce 1997 pak v Praze nákladem Jednoty klasických filologů publikoval svoji vyčerpávající bibliografii „Československá právna romanistika v rokoch 1882-1945. BIBLIOGRAPHIA STUDIORUM AD IUS ROMANUM PERTINENTIUM IN BOHEMOSLOVENIA MDCCCLXXXII". 3

To, čím se však skutečně významně zapsal do historie české i slovenské právní romanistiky, byla jeho iniciativa vedoucí k založení každoročních setkání českých a slovenských právních romanistů. $Z$ jejich skromných počátků, kdy se jejich účastníci vešli k většímu stolu, se staly konferencemi v pravém slova smyslu o mnoha přednášejících. Nepochybně i tato vědecká setkání, v jejichž pořádání se pravidelně střídají právnické fakulty obou republik, přispěla ke znovuoživení rímského práva. Právě na nich získávají mladí kolegové první zkušenosti s konferenčním vystoupením a s odbornou diskusí, které pak zúročují na velkých akcích v zahraničí. Růst počtu účastníků, spolu s jejich výrazným omlazováním, byly pro prof. Blaha značným zadostiučiněním. Je proto velká škoda, že mu nemoc

Právněhistorické studie, 1977, 20, s. 229-251.

2 Právněhistorické studie (Doplněk), 1978, 21, s. 347-349; Štát a právo antického Ríma. Bibliografia československých štúdií za roky 1976-1985 (Právněhistorické studie, 1989, 30, s. 125-149).

3 Avriga. Zprávy Jednoty klasických filologů. Praha, 1997, XXXIX, 2, 68 s. 
neumožnila zúčastnit se letošního jubilejního, již 20. setkání, jehož pořadatelem byla právnická fakulta $v$ Košicích.

Tolik k nejdůležitější Blahově organizační česko-slovenské aktivitě, přičemž své členství v redakční radě Právněhistorických studií, stejně jako v různých komisích při obhajobách kandidátských (mimo jiné i autora této vzpomínky) a poté doktorských prací, stejně jako to, že se pod jeho vedením na trnavské právnické fakultě habilitovala doc. Židlická, považoval za zcela samozřejmé.

Za neméně důležité musíme brát jeho spolupráci vědeckou, respektive př̌kladatelskou. Byla to jeho idea zprostředkovat bohatství římského práva také současným právníkům, jimž latina již není vlastní, a také dalším zájemcům o římský starověk, která stála na jejich počátku. V roce 2000 vydal Peter Blaho svůj překlad justiniánské učebnice práva ${ }^{4}$ a odtud již zbýval jen malý krok k realizaci myšlenky vydat, z důvodů odlišné právní terminologie ve slovenštině a v češtině, také jeho české znění. Peter Blaho tak „,vyprovokoval“ založení ediční řady Fontes iuris romani nakladatelství Karolinum, kde převod jeho překladu do češtiny doplněný o poznámkový aparát a rejstříky doprovázející i další díly, pořízené autorem tohoto textu, vyšel v roce $2010^{5}$ jako první svazek zmíněné edice.

Následoval daleko šířeji pojatý společný překladatelský projekt. Profesor Blaho sáhl po Digestech, přičemž plánoval vydat překlad zajímavých titulů z nich ve dvou dílech. První díl ${ }^{6}$ se tak stal podkladem pro druhý svazek edice Fontes iuris romani. Tentokrát se již nejednalo o „převzetí“ s slovenského překladu, ale ten byl doplněn a rozšířen na téměř dvojnásobek. Peter Blaho navíc pro tuto edici zpracoval předmluvu, medailony římských právníků a především obsáhlou bibliografickou přílohu. Nakladatelství Karolinum pak tento společný projekt vydalo pod titulem ,Digesta seu Pandectae, tomus I, liber I-XV, fragmenta selecta/Digesta neboli Pandekty, svazek I, kniha I-XV, vybrané části."7 Zároveň pokračovala př́íprava druhého dílu slovenského překladu i jeho rozšsiřrené české verze. Práce na slovenském vydání druhého dílu překladu Digest v souvislosti s horšícím se Blahovým zdravotním stavem postupně ustávaly a publikace českého rozšířeného vydání, které se nachází ve finální fázi dokončení, se již bohužel nedočkal.

Tak tomu také bohužel bude se třetím dílem českého překladu Digest, k němuž Peter Blaho stačil připravit překlad již jen několika málo titulů. Stejně tak již nebude realizován projekt společné česko-slovenské učebnice římského práva, o němž jsme uvažovali, ani výkladového slovníku tohoto právního řádu.

Jen málo vědeckých osobností právní romanistiky bylo tak úzce spojeno s oběma částmi našeho bývalého společného státu. Snad to byl jen profesor Otakar Sommer, jehož portrét zdobil Blahovu pracovnu, a který visí dodnes na katedře římského, kanonického a církevního práva právnické fakulty Univerzity Komenského v Bratislavě.

A tak místo vzletných slov na závěr, jen říkám: Děkujeme, Peter.

doi: 10.14712/2464689X.2018.48

Michal Skřejpek

4 Corpus Iuris Civilis. Justinánske Inštitúcie. Trnava: Wolters Kluwer, 2000, 439 s.

5 Iustiniani Institutiones/Justinánské Instituce. Praha: Karolinum, 2010, $411 \mathrm{s.}$

6 Corpus iuris civilis. Digesta, Tomus I. Bratislava: Eurokódex, 2008, 525 s.

7 Praha: Karolinum, 2015, 701 s. 